\title{
The role of flagella, but not fimbriae, in the adherence of Salmonella enterica serotype Enteritidis to chick gut explant
}

\author{
EMMA ALLEN-VERCOE and MARTIN J. WOODWARD* \\ Centre for Applied Microbiology and Research, Porton Down, Salisbury, Wiltshire SP4 OJG and *Bacteriology \\ Department, Central Veterinary Laboratory, Addlestone, Surrey KT15 3NB
}

\begin{abstract}
To gain an understanding of the role of fimbriae and flagella in the adherence and colonisation of Salmonella enterica serotype Enteritidis in chickens, an in-vitro gut adherence assay was developed and used to assess the adherence of a wild-type Enteritidis strain and isogenic non-fimbriate and non-flagellate mutant strains. Enteritidis strain $\mathbf{S 1 4 0 0 / 9 4}$, a clinical isolate virulent in chickens, was shown to possess genes which encoded type 1, SEF14, SEF17, plasmid-encoded and long polar fimbriae. Mutant strains unable to elaborate these fimbriae were created by allelic exchange. Each fimbrial operon was inactivated by the insertion of an antibiotic resistance gene cassette. In addition, $f i C$, mot $A B$ and $\operatorname{che} A$ loci, which encode the major subunit of the flagellum, the energy-translation system for motility and one of the chemotaxis signalling proteins, respectively, were similarly inactivated. Non-flagellate mutant strains were significantly less adherent than the wild-type strain, whereas mutant strains defective for the elaboration of any of the types of fimbriae adhered as well as the wild-type strain. A flagellate but non-motile (paralysed) mutant strain and a smooth-swimming chemotaxisdeficient mutant strain were shown to be less adherent than the wild-type strain, but that observation depended on the assay conditions used.
\end{abstract}

\section{Introduction}

The role of fimbriae and flagella in the pathogenesis of Salmonella has become a focus of recent research interest. For $S$. enterica serotype Typhimurium, type 1 fimbriae, which mediate mannose-sensitive haemagglutination and have been assumed to play a role in initial gut colonisation [1], and flagella have been demonstrated to play a key role in pathogenesis in a mouse model [2-4] and in chickens [5,6]. Long polar fimbriae (LPF) [7] mediate adherence to murine $M$ cells in Peyer's patches $[8,9]$ and plasmid-encoded fimbriae (PEF) [10] mediate adherence to murine small intestine with reduced intraluminal fluid accumulation [11].

For serotype Enteritidis a role has been demonstrated for type 1 fimbriae - also referred to as SEF21, a designation used in this report - and for type 3 fimbriae in pathogenesis in a mouse model [12], but relatively little is yet understood about the role of

Received 25 Aug. 1998; revised version accepted 7 Dec 1998.

Corresponding author: Professor M. J. Woodward. fimbriae in chickens. Enteritidis has been shown to elaborate an analogue of PEF that is expressed during infection in the chicken [13] and has the genetic potential to elaborate LPF [7]. Enteritidis also elaborates an analogue of the 'curli' fimbriae of Escherichia coli [14] - designated SEF17 [15,16] - that are essential for the generation of convoluted colonies during growth of Enteritidis at ambient temperatures on Colonisation Factor Antigen (CFA) agar [17]. It is of interest that colonies of Enteritidis derived by direct plating of infected chicken livers and spleens on to selective media, developed convoluted morphology [18]. A subset of serotypes of Salmonella of Oserogroup D, and including Enteritidis, elaborate a novel kind of fimbriae designated SEF14 [19-21]. However, the role of SEF14 in pathogenesis remains equivocal [22], although a two-thirds reduction in the adherence of Enteritidis to ovarian granulosa cells in vitro was demonstrated by pre-incubation of bacteria with purified SEF14 fimbriae [23]. Anti-SEF14 antibodies have also been shown to afford a degree of passive protection in a mouse model [24].

Together, these observations suggest that fimbriae may play a role in the pathogenesis of Enteritidis. However, 
this hypothesis remains largely untested, particularly in chickens. Accordingly, the roles of fimbriae and flagella were assessed in a reverse genetics approach in which a series of non-fimbriate and non-flagellate mutant strains was derived for studies in vitro and in vivo. This paper describes the construction of these mutant strains and their in-vitro adherence properties in an explant model of day-old chick gut.

\section{Materials and methods}

\section{Bacteria, plasmids and media}

Bacterial strains and plasmids used in this study are listed in Table 1. Bacterial cultures were maintained as frozen $\left(-70^{\circ} \mathrm{C}\right)$ stocks in Luria-Bertani (LB) broth [30] supplemented with glycerol $15 \%$. Working cultures were maintained at $4^{\circ} \mathrm{C}$ on plates of LB agar appropriately supplemented with antibiotics. Minimal growth medium was M9 salts supplemented with glucose $0.2 \% \mathrm{w} / \mathrm{v}$ and $10 \mathrm{mM}$ magnesium [30]. Bacteria for SEF21 ELISA were grown statically in Heart Infusion Broth (Oxoid) at $37^{\circ} \mathrm{C}$ for $48 \mathrm{~h}$. Bacteria for SEF17 ELISA were grown on Colonisation Factor Antigen (CFA) Agar (Oxoid) at $25^{\circ} \mathrm{C}$ for $48 \mathrm{~h}$. Bacteria for SEF14 ELISA were grown in IsoSensitest Broth (Oxoid) at $37^{\circ} \mathrm{C}$ for $24 \mathrm{~h}$. For gut-adherence assays, bacteria were grown overnight at $37^{\circ} \mathrm{C}$ in $\mathrm{LB}$ broth without agitation, pelleted by centrifugation at $3000 \mathrm{~g}$ for $10 \mathrm{~min}$ and resuspended gently in PBS to an $\mathrm{OD}_{550}$ of 0.6 .

\section{Slide agglutination}

Individual colonies grown on LB agar were emulsified in $50 \mu \mathrm{l}$ of PBS to which an equal volume of agglutination serum (Central Veterinary Laboratory, Addlestone, Surrey) was added. Slides were incubated at room temperature with rocking for no more than $5 \mathrm{~min}$. For haemagglutination tests, the above procedure was used but with guinea-pig red blood cells (Sigma) 3\% added instead of antiserum.

\section{Genetic methods}

Methods for the extraction and purification of plasmid and chromosomal DNA, restriction endonuclease digestion, agarose gel electrophoresis, ligation, preparation of electrocompetent bacterial cells, electroporation, lysis of bacterial colonies for colony dot-blot on, and Southern transfer of DNA species to Hybond-N nylon membranes (Amersham) and autoradiography were as described previously [30].

\section{PCR}

The methods have been described elsewhere [13]; primers for antibiotic resistance, fimbrial and flagellar genes, and their sources, are listed in Table 2.

\section{Cloning and insertional inactivation of fimbrial and flagellar genes}

DNA fragments, which encoded relevant regions of fim, agf, pef, lpf operons, the $f i C$ and $c h e A$ genes and the mot $A B$ regulon, were amplified by PCR. These fragments were subcloned separately into pCRSCRIPT (Stratagene) and inserts were confirmed by preliminary nucleotide sequence analysis and detailed restriction endonuclease mapping (data not shown). Antibiotic resistance gene cassettes were cloned separately into the $f i m D, a g f A$, pefA, lpfC, $f i C$, che $A$ and mot $A B$ genes, either by direct subcloning, if appropriate restriction endonuclease sites were available within the open reading frames, or by splice overlap extension PCR. The insertionally inactivated fimbrial operon regions were subcloned on to appropriate pERFORM vectors and electroporated into the permissive host Escherichia coli strain K12 S-17 $\lambda$ pir. Cloning and mutagenesis strategies are summarised in Table 3.

\section{Conjugation}

The pERFORM vectors harbouring antibiotic resistance-marked, insertionally inactivated genes (see Table 3 , column $8, \mathrm{pSCV}$ derivatives) were transferred by conjugation from the permissive host strain $E$. coli $\mathrm{K} 12$

Table 1. Bacterial strains and plasmids

\begin{tabular}{|c|c|c|}
\hline Bacterial strain/plasmid & Reference no. & Comments \\
\hline E. coli $\mathrm{JM} 109 \lambda$ pir & 25 & 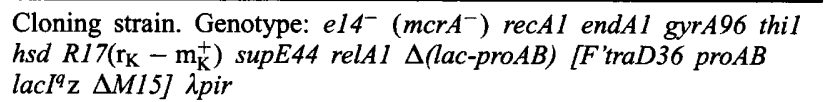 \\
\hline E. coli S-17 $\lambda$ pir & 26 & $\begin{array}{l}\text { Mobilising strain. Genotype: pro res } \bmod ^{+} \mathrm{RP} 42-\mathrm{Tc}:: \mathrm{Mu}^{-} \mathrm{Km}:: \mathrm{Tn} 7 \\
\lambda \text { pir }\end{array}$ \\
\hline Enteritidis S1400/94 & 13 & Wild-type strain \\
\hline Enteritidis LA5 & 27 & Wild-type strain LA5 \\
\hline Enteritidis LA5SEF14- & 22 & $\operatorname{sef} A:: \operatorname{kan}^{\mathrm{R}}$ \\
\hline pACYC184 & 28 & Source of tet ${ }^{\mathrm{R}}$ cassette \\
\hline pCRSCRIPT & Commercially available (Stratagene) & Direct PCR cloning vector \\
\hline pR751 & 29 & Source of tri ${ }^{\mathrm{R}}$ cassette \\
\hline pZERO-1 & Commercially available (Invitrogen) & Source of $\mathrm{zeo}^{\mathrm{R}}$ cassette \\
\hline pJP5603 & 25 & $\mathrm{kan}^{\mathrm{R}}$ suicide vetor \\
\hline pERFORM K & This study & pJP5603 with modified MCS \\
\hline pERFORM C & This study & $\begin{array}{l}\text { pJP5603 with modified MCS and } \text { kan }^{R} \text { marker replaced with } \text { cam }^{R} \\
\text { marker }\end{array}$ \\
\hline
\end{tabular}


Table 2. Primer sequences

\begin{tabular}{|c|c|c|c|}
\hline Primer name & Sequence $5^{\prime}-3^{\prime}$ & Position on target gene/operon & Reference no. \\
\hline AGF1 & ATGATGTTGACAATACTGGGT & $278-301$ of $a g f B$ & 16 \\
\hline AGF2 & TGATAAATGCAGTGATTGTCC & $22-43$ of $a g f C$ & \\
\hline CHEA1 & AGGTGATAGCGTGAGCATGGA & $1-21$ of cheA & 31 \\
\hline CHEA2 & TGTGATCGCCATACGTTGTTC & $1998-2018$ of cheA & \\
\hline FIMD1 & GGCTATGTATCACCGTTAAGC & $36-57$ of $f i m D$ & 32 \\
\hline FIMD2 & TATGGTAATCGCCTGCTTCAG & $2559-2580$ of $\mathrm{fimD}$ & \\
\hline FLIC1 & ACTGAGTCCCGATAACGCTAACGA & $183-209$ of $f i C$ & 33 \\
\hline FLIC2 & TTATTACGTTGCATAGTCAGCATCTTC & $1392-1413$ of $\mathrm{fiC}$ & \\
\hline LPFC1 & ATGACATGGACGCATCTTCCT & $1-21$ of $l p f C$ & 7 \\
\hline LPFC2 & CCAACAGGCCCGTAAACACATTA & $16-36$ of $l p f D$ & \\
\hline MOT1 & GAGCTCAAGGATGATGTCGTGCTTATC & $13-34$ of mota & \\
\hline MOT2 & AGATCTTGCTGGTTTGGGTACCTCACT & $845-865$ of $m o t A$ & 34 \\
\hline MOT3 & AGATCTTGGAAAATTGCCTACGCCGAT & $78-99$ of $\operatorname{motB}$ & \\
\hline MOT4 & TCTAGATATCACCTCGGTTCCGCTTTT & $911-931$ of $\operatorname{mot} B$ & \\
\hline PEFA1 & GAATGCTGACGGCTTTGGTGC & $287-312$ of pefA & 13 \\
\hline PEFC2 & TGGTCTGCAGCTCCAGGTCATC & $2085-2113$ of pefC & 10 \\
\hline TET 1 & CAGTTACCTCGGTTCAAAGAG & $1278-1299$ of pACYC184 & 35 \\
\hline TET2 & CAATTCTTGGAGTGGTGAATC & $2797-2818$ of $\mathrm{pACYC} 184\}$ & \\
\hline TRIM1 & GAATTCTTAGGCCACGCGTTC & $1-21$ of $\mathrm{pR} 751$ & 29 \\
\hline TRIM2 & AGGCACGAACCCAGTTGACAT & $577-556$ of pR751 & \\
\hline
\end{tabular}

S-17 $\lambda$ pir into the non-permissive Enteritidis strain S1400 by filter mating. Equal volumes $(100 \mu \mathrm{l})$ of overnight broth cultures of donor and recipient strains were inoculated together, or separately, as controls, on sterile $2-\mu \mathrm{m}$ filters overlaid on dried plates of nutrient agar and incubated at $37^{\circ} \mathrm{C}$. After growth for $4 \mathrm{~h}$ cultures were removed from filters by immersion and vigorous agitation in PBS. Dilutions were plated on to selective media which were glucose minimal medium supplemented with appropriate antibiotics.

\section{Selection of mutant strains}

Individual colonies from conjugation selective plates were streaked on to fresh glucose minimal medium supplemented with appropriate antibiotic, (i.e., the antibiotic to which resistance was encoded by the insert of inactivated gene) and grown overnight at $37^{\circ} \mathrm{C}$. Individual colonies were tested for loss of the antibiotic resistance encoded by the suicide vector. Putative mutant colonies were picked from the master plate and re-streaked for single colonies on LB agar for confirmatory tests.

\section{P22 transduction}

Preparation of multiply mutant strains in the Enteritidis strain S1400 background was achieved by P22 transduction [36] with selection for antibiotic resistance encoded within the mutant alleles.

\section{Colony dot-blot and Southern hybridisation}

Probes were prepared either by PCR or direct excision of the relevant gene fragment or were entire pERFORM vectors without inserts. Radioisotopic labelling with ${ }^{32} \mathrm{P}$ (Amersham RapidHyb), hybridisation conditions and stringency of post-hybridisation washes were as described previously [13].

\section{Fimbria-specific ELISAs}

ELISAs specific for SEF21 [37], SEF17 [38] and SEF14 [39] were used to assay elaboration of fimbriae.

\section{Adherence assay in chicken gut explants}

The method for preparation of tissues followed those described previously $[5,40]$. In brief, 1-day-old SPF chicks were killed by cervical dislocation and the duodenal loop, $c .6 \mathrm{~cm}$ in length, was removed aseptically. Fat and mesentery were removed carefully and the gut section was cut lengthwise and washed thoroughly, but gently, in Krebs's Ringers solution. Gut segments $(c .2 .0 \times 0.5 \mathrm{~cm})$ were immersed in fresh sterile Krebs's Ringers $(20 \mathrm{ml})$ in a $50-\mathrm{ml}$ Falcon tube (BDH) to which the bacterial inoculum of $c$. $4 \times 10^{8} \mathrm{cfu}(2 \mathrm{ml})$ was added. Incubation was continued at $42^{\circ} \mathrm{C}$ with orbital rotation at $225 \mathrm{rpm}$. Gut samples were rinsed three times in fresh sterile Krebs's Ringers solution to remove non-adherent bacteria, and serial dilutions of homogenates were plated in triplicate. All experiments were repeated at least three times.

\section{Scanning electron microscopy (SEM)}

Gut specimens were fixed for $16 \mathrm{~h}$ in glutaraldehyde $3 \% \mathrm{v} / \mathrm{v}$ in $0.1 \mathrm{M}$ phosphate buffer, $\mathrm{pH} 7.4$, washed in phosphate buffer and post-fixed in osmium tetroxide $1 \% \mathrm{w} / \mathrm{v}$ in the same buffer. Specimens were rinsed in six changes of phosphate buffer, dehydrated in ethanol and placed in acetone. Specimens were subjected to critical point drying with liquid $\mathrm{CO}_{2}$. Dried specimens were fixed to aluminium stubs with silver conductive paint, sputter-coated with gold and examined in a stereoscan S250 MarkIII SEM at $10-20 \mathrm{kV}$. 


\section{Results \\ Construction and confirmation of mutant strains of Enteritidis $\mathbf{S 1 4 0 0}$}

Southern hybridisation of each mutant strain of Enteritidis strain S1400 confirmed that the native fimbrial or flagellar gene had been altered, as predicted by the insertion of the known antibiotic resistance gene cassette (Fig. 1); no hybridisation was observed when pERFORM plasmid DNA alone was used as probe, which confirmed the loss of the suicide vector. Where possible, the phenotype of each mutant strain was confirmed and data are summarised in Table 4. It was not possible to demonstrate in-vitro expression of either LPF of PEF fimbriae by Enteritidis and the study relied upon hybridisation data (Fig. 1) that EAV7 (S1400 $\left.l p f C:: \mathrm{trm}^{\mathrm{r}}\right)$ and EAV5 (S1400 pefC::zeo ${ }^{\mathrm{r}}$ ) were genuine non-fimbriate mutant strains. Multiply mutant strains were prepared by P22 transduction, and co-transduction frequencies between the antibiotic resistance marker and mutant phenotype (where testable) were $100 \%$. In addition, all transductants were confirmed by Southern hybridisation to have acquired the modified alleles. The in-vitro growth rates of all mutant strains in LB broth shaken at $37^{\circ} \mathrm{C}$ were similar to the wild-type strain.

\section{Development of a chick gut explant model}

To estimate the extent of natural microflora colonisation of the alimentary tract of the day-old chick before inoculation with test bacterial cultures, gut sections from two chicks were homogenised and plated on nutrient agar with incubation at $37^{\circ} \mathrm{C}$ for $24-48 \mathrm{~h}$. Bacterial growth was not detected. All subsequent assays included a measurement of bacterial colonisation from a control chick selected at random. SEM was used to test whether bacteria adhered to serous and luminal surfaces of the explant tissue. Enteritidis strain S1400 was incubated for $1 \mathrm{~h}$ with tissue samples and 25 fields of view of each surface were examined for adherent bacteria (Fig. 2a, b). Mean counts of 14 and 191 were determined for serous and luminal surfaces, respectively, and this difference was highly significant $(\mathrm{p}<0.001)$. To determine whether Enteritidis was more adherent for any specific region of day-old chick gut, adhesion assays were performed with strain $\mathrm{S} 1400$ for 1 and $3 \mathrm{~h}$ on $2-\mathrm{cm}$ gut samples taken from duodenum, proximal and distal small intestine, caecal and rectal regions. No significant differences in mean counts between the tissue types or incubation times $(p=0.172$ for $1 \mathrm{~h} ; \mathrm{p}=0.113$ for $3 \mathrm{~h}$ ) were observed. The duodenal loop was chosen for further studies.

\section{Adherence of mutant strains of Enteritidis to duodenal gut sections}

Wild-type and singly mutant strains from the Enteritidis S1400 mutant library were assessed for their ability to adhere (Table 5). The adherence of the nonflagellate mutant strain EAV9 was significantly reduced 
a

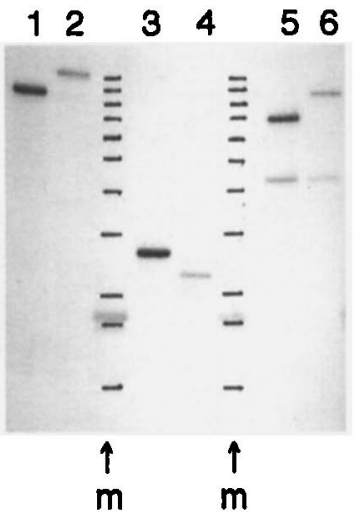

C

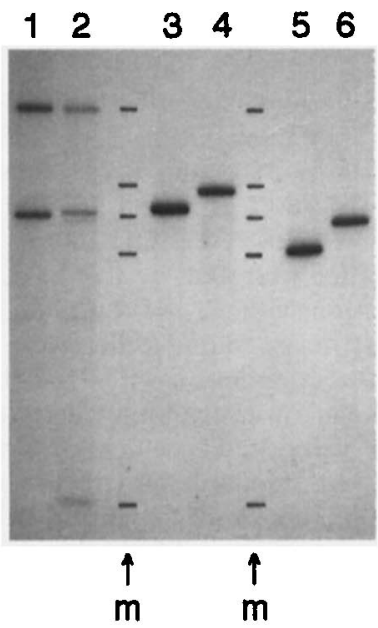

e

123456

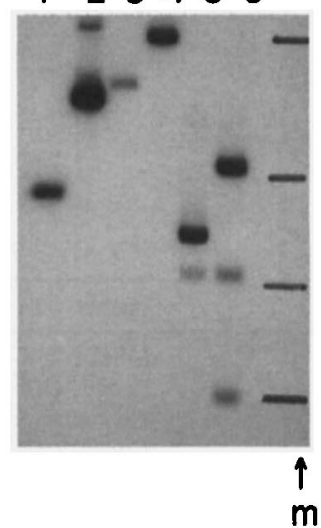

b
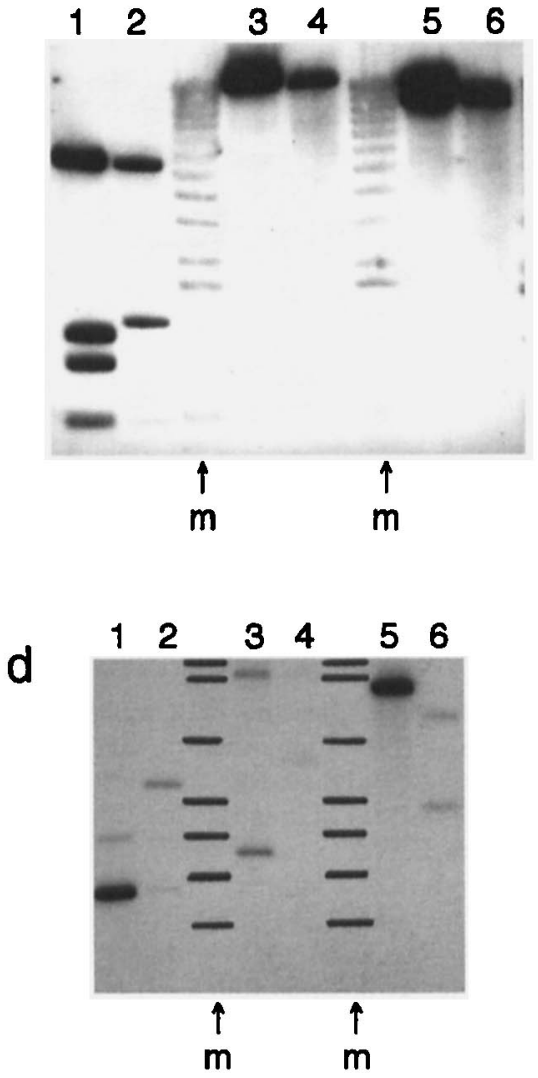

f
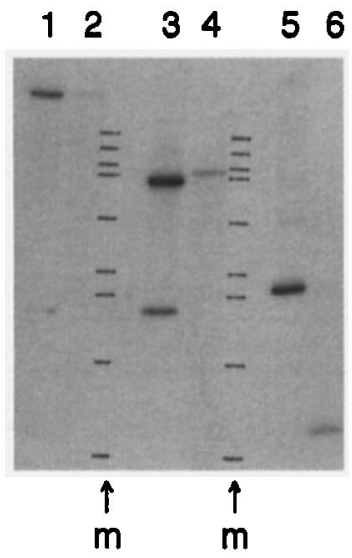

Fig. 1. (continued overleaf)

compared with that of the wild-type strain $(p<0.001$, for both incubation periods). To test whether fimbriae and flagella exerted synergic effects on adherence, multiply mutant strains were similarly assessed (Table 5). In comparison with the wild-type strain, the adherence of strain EAV37 (non-flagellate, non-motile and non-fimbriate) was significantly reduced ( $p<0.001$ after both 1 and $3 \mathrm{~h}$ ) whereas mutant strain EAV26 (motile, flagellate and non-fimbriate) showed no significant differences $(p=0.791$ for $1 \mathrm{~h} ; \mathrm{p}=0.082$ for $3 \mathrm{~h})$.
Adherence of non-flagellate, paralysed and chemotaxis-defective mutants to gut explants

Decreased adherence of non-flagellate mutant strains may have resulted from either lack of the organelle itself or lack of motility or chemotactic ability. Accordingly, to evaluate these possibilities, a paralysed, flagellate but non-motile mutant strain (EAV45) and a chemotaxis-defective, smooth-swimming mutant strain (EAV65) were constructed. These mutant strains were compared with the wild-type strain S1400 for adherence in each of three assays in which the gut explants 

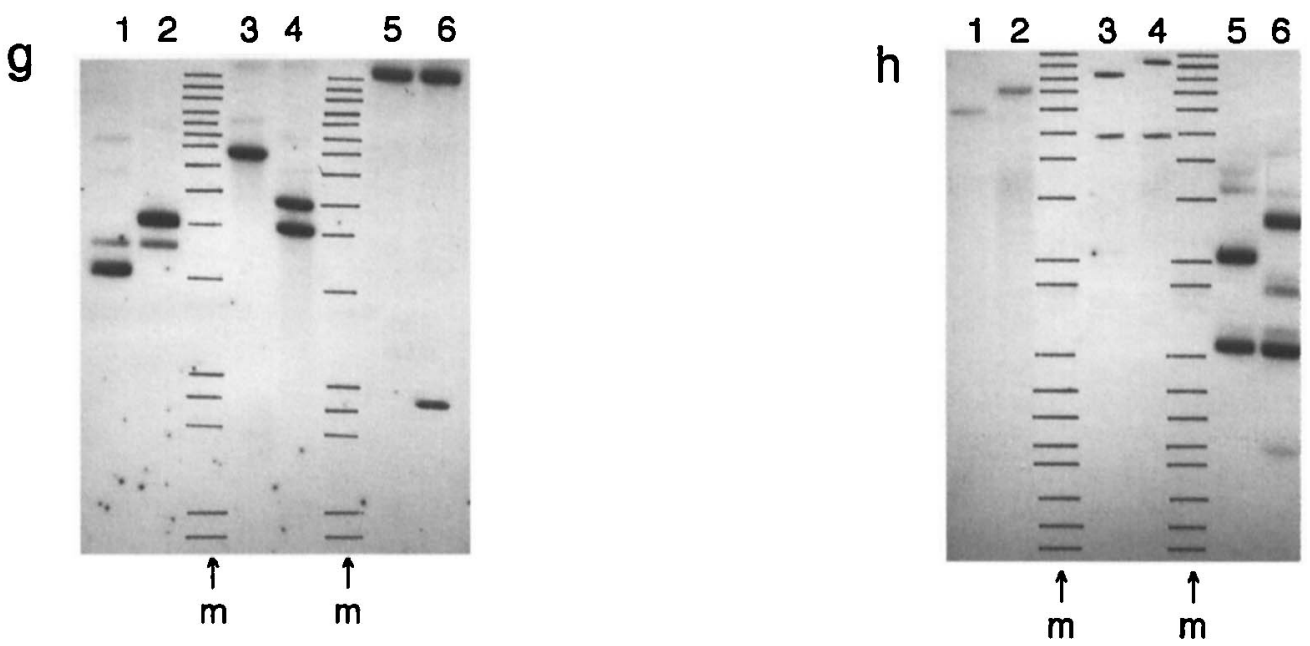

Fig. 1. Southern hybridisation of genomic DNA of Enteritidis strain S1400/94 and isogenic strains derived from it to demonstrate insertional inactivation of target fimbrial and flagellar genes. (a) Lanes 1, 3, 5, S1400; 2, 4, 6, EAV1

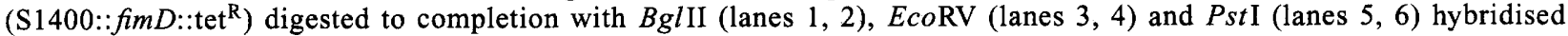
against fimD. Mol.-wt standards (m) were in ascending order, 1, 1.6, 2, 3, 4, 5, 6, 7, 8, 9 and $10 \mathrm{~kb}$. (b) Lanes 2, 4, 6, S1400; 1, 3, 5, EAV5 $\left(\mathrm{S} 1400::\right.$ pefC::zeo $^{\mathrm{R}}$ ) digested to completion with SmaI (lanes 1, 2), SalI (lanes 3, 4) and HindIII (lanes 5,6) hybridised against pefC. Mol.-wt standards (m) in ascending order were $0.4,1,1.6,5,6,9$ and $11 \mathrm{~kb}$. (c) Lanes 1, 3, 5, S1400; 2, 4, 6, EAV7 (S1400::lpfC::trm ${ }^{\mathrm{R}}$ ) digested to completion with EcoRI (lanes 1, 2), EcoRV (lanes 3, 4) and Ssp I (lanes 5, 6) hybridised against lpfC. Mol.-wt standards (m) in ascending order were 0.5, 3, 4, 5 and $10 \mathrm{kp}$. (d) Lanes 1, 3, 5, S1400; 2, 4, 6, EAV9 $\left(\mathrm{S} 1400:: f i C::\right.$ cam $^{\mathrm{R}}$ ) digested to completion with Pst I (lanes 1,2$), P v u$ II (lanes 3,4) and SspI (lanes 5,6) hybridised against $f i C$. Mol.-wt standards (m) in ascending order were 0.5, 1, 1.6, 2, 3,4 and $5 \mathrm{~kb}$. (e) Lanes 1, 3, 5, S1400; 2, 4, 6, EAV11 $\left(\mathrm{S} 1400:: a g f A:: \mathrm{amp}^{\mathrm{R}}\right)$ digested to completion with HpaI (lanes 1, 2), SalI (lanes 3,4) and Ssp I (lanes 5, 6) hybridised against fliC. Mol.-wt standards (m) in ascending order were $0.5,1,1.6,2,3$ and $4 \mathrm{~kb}$. (f) Lanes 1, 3, 5, S1400; 2, 4, 6, EAV13 (S1400::sefA::kan ${ }^{\mathrm{R}}$ ) digested to completion with DraI (lanes 1, 2), HindIII (lanes 3,4) and NruI (lanes 5,6) hybridised against sefA. Mol.-wt standards (m) in ascending order were $0.5,1,1.6,2,3,4,5,6$ and $7 \mathrm{~kb}$. (g) Lanes 1, 3, 5, S1400; 2, 4, 6, EAV45 $\left(\mathrm{S} 1400::\right.$ mot $A B:: \mathrm{cam}^{\mathrm{R}}$ ) digested to completion with EcoRV (lanes 1, 2), KpnI (lanes 3, 4) and NcoI (lanes 5, 6) hybridised against motAB. Mol.-wt standards (m) in ascending order were $0.1,0.2,0.6,0.8,1,2,3,4,5,6,7,8,9,10$, 11 and $12 \mathrm{~kb}$. (h) Lanes 1, 3, 5, S1400; 2, 4, 6, EAV65 $\left(\mathrm{S} 1400:\right.$ :cheA::cam $\left.{ }^{\mathrm{R}}\right)$ digested to completion with KpnI (lanes 1, 2), Pst I (lanes 3,4) and SspI (lanes 5, 6) hybridised against cheA. Mol.-wt standards (m) in ascending order were $0.1,0.2,0.4,0.6,0.8,1,1.5,2,3,4,5,6,7,8,9$ and $10 \mathrm{~kb}$.

Table 4. Genotypes and phenotypes of Enteritidis S1400 mutant strains

\begin{tabular}{|c|c|c|c|c|}
\hline Mutation & Strain designation & Genotype & Antibiotic resistance $(\mathrm{mg} / \mathrm{L})$ & Phenotype of mutant \\
\hline SEF21- & EAV1 & fimD::tet ${ }^{\mathrm{R}}$ & Tetracycline* $(6)$ & $\mathrm{MSHA}^{-} ; \mathrm{SEF}^{2} 1 \mathrm{ELISA}^{-}$ \\
\hline SEF17 $7^{-}$ & EAV $11^{\dagger}$ & $\operatorname{agf} A:: \mathrm{amp}^{\mathrm{R}}$ & Ampicillin* (25) & Lacy $^{-}$; SEF 17 ELISA $^{-}$ \\
\hline $\mathrm{PEF}^{-}$ & EAV5 & pefC::zeo ${ }^{\mathrm{R}}$ & Zeocin $(25)$ & Unconfirmed \\
\hline $\mathrm{LPF}^{-}$ & EAV7 & lpfC:: trim $^{\mathrm{R}}$ & Trimethoprim (20) & Unconfirmed \\
\hline $\mathrm{FLA}^{-}$ & EAV9 & $f i C:: \mathrm{cam}^{\mathrm{R}}$ & Chloramphenicol (10) & Non-motile $\mathrm{H} \mathrm{g}, \mathrm{m}^{-}$ \\
\hline MOT $^{-}$ & EAV45 & $m o t A B: \mathrm{cam}^{\mathrm{R}}$ & Chloramphenicol (10) & Non-motile $\mathrm{H} \mathrm{g}, \mathrm{m}^{+}$ \\
\hline $\mathrm{CHE}^{-}$ & EAV65 & cheA:: cam $^{\mathrm{R}}$ & Chloramphenicol (10) & Smooth swimming $\mathrm{H} \mathrm{g}, \mathrm{m}^{+}$ \\
\hline SEF14- & EAV 13* & $\operatorname{sef} A: \operatorname{kan}^{\mathrm{R}}$ & Kanamycin $(50)$ & SEF 14 ELISA $^{-}$ \\
\hline $\mathrm{FLA}^{-}$ & & $f i C::$ cam $^{\mathrm{R}}$ & Chloramphenicol (10) & Non-motile, $\mathrm{H}$ g,m- \\
\hline SEF $\left.21^{-}\right\}$ & EAVJS & fimD:: tet $^{\mathrm{R}}$ & Tetracycline (6) & $\mathrm{MSHA}^{-}$SEF $1 \mathrm{ELISA}^{-}$ \\
\hline SEF21 ${ }^{-}$ & & fimD::tet ${ }^{\mathrm{R}}$ & Tetracycline $(6)^{*}$ & $\mathrm{MSHA}^{-}$ \\
\hline SEF $17^{-}$ & & $a g f A:: a m p^{\mathrm{R}}$ & Ampicillin $(25)^{*}$ & Lacy $^{-}$ \\
\hline $\mathrm{PEF}^{-}$ & EAV26 & pefC::zeo ${ }^{\mathrm{R}}$ & Zeocin $(25)$ & SEF21 ELISA- \\
\hline $\mathrm{LPF}^{-}$ & & $l p f C::$ trim $^{\mathbf{R}}$ & Trimethoprim (20) & SEF17 ELISA ${ }^{-}$ \\
\hline SEF14- & & sef $A: \mathrm{kan}^{\mathrm{R}}$ & Kanamycin $(50)$ & SEF14 ELISA ${ }^{-}$ \\
\hline SEF $21^{-}$ & & fimD::tet ${ }^{\mathrm{R}}$ & Tetracycline $(6)^{*}$ & $\mathrm{MSHA}^{-}$ \\
\hline SEF17- & & $\operatorname{agf} A:: \mathrm{amp}^{\mathrm{R}}$ & Ampicillin $(25)^{*}$ & $\mathrm{Lacy}^{-}$ \\
\hline $\mathrm{PEF}^{-}$ & & pefC::zeo ${ }^{\mathrm{R}}$ & Zeocin $(25)$ & SEF21 ELISA ${ }^{-}$ \\
\hline $\mathrm{LPF}^{-}$ & EAV37 & lpfC:: trim $^{\mathrm{R}}$ & Trimethoprim (20) & SEF17 ELISA ${ }^{-}$ \\
\hline SEF14 ${ }^{-}$ & & $\operatorname{sef} A:: \mathrm{kan}^{\mathrm{R}}$ & Kanamycin $(50)$ & SEF14 ELISA ${ }^{-}$ \\
\hline $\mathrm{FLA}^{-}$ & & $f i C:: \mathrm{cam}^{\mathrm{R}}$ & Chloramphenicol (10) & Non-motile $\mathrm{H} g, \mathrm{~m}^{-}$ \\
\hline
\end{tabular}

MSHA, mannose-sensitive haemagglutination.

* Only one copy of resistance gene resides within mutant chromosome, thus conferred level of resistance to antibiotics is low [41].

${ }^{\dagger}$ Described in ref. [17] and included here for completeness.

${ }^{\ddagger}$ Produced by transduction of $s e f A:: \mathrm{kan}^{\mathrm{R}}$ from Enteritidis strain LA5SEF14- ${ }^{-}$22] to Enteritidis strain S1400. 

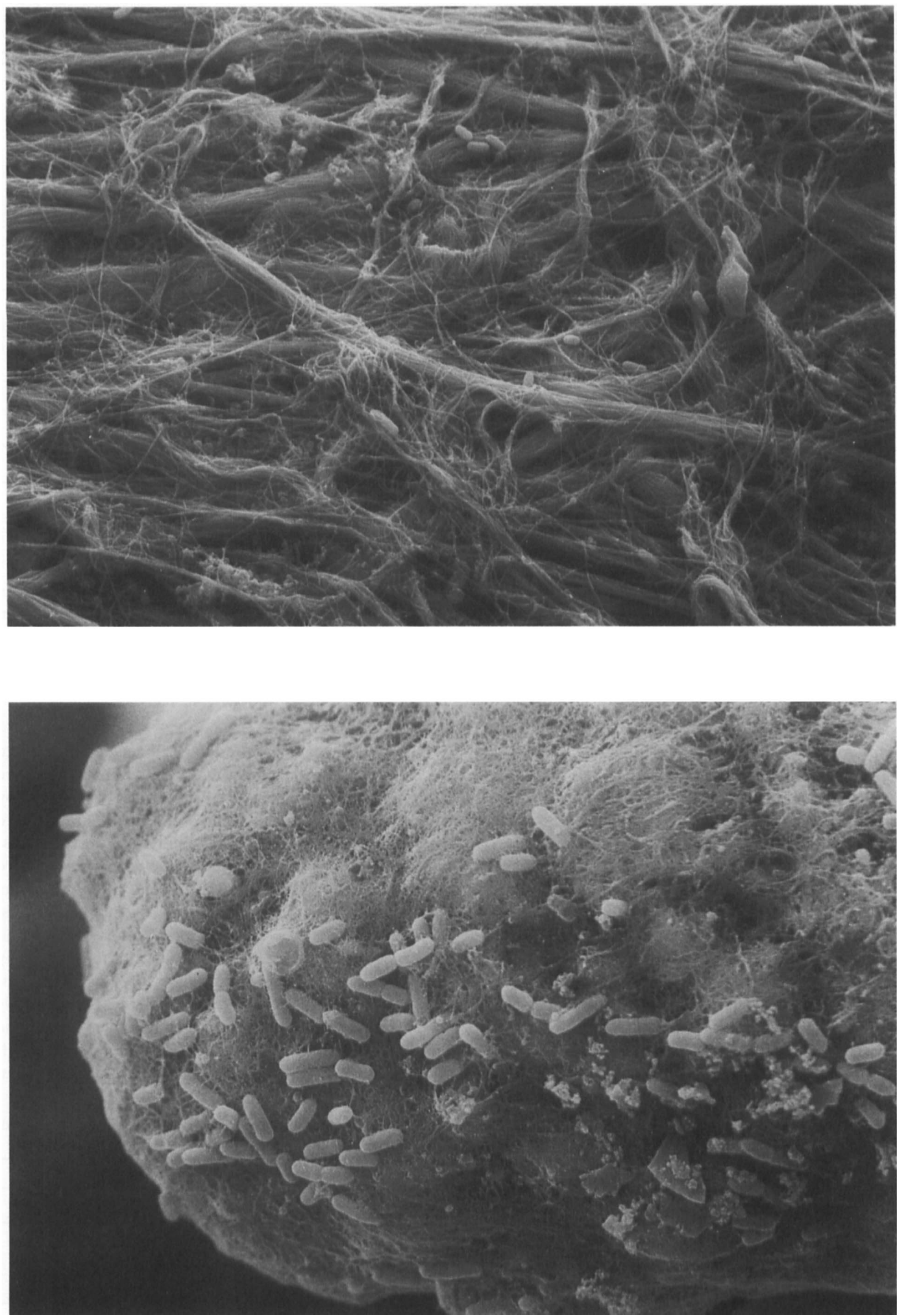

Fig. 2. Scanning electron micrograph of serous (a) and lumenal (b) surfaces of chick gut duodenal tissue samples exposed to Enteritidis strain S1400/94 for $1 \mathrm{~h}$ in standard adherence assay. Bar $=10 \mu \mathrm{m}$. 
Table 5. Mean bacterial counts of wild-type, singly and multiply mutant strains bound to duodenal gut explants from day-old chicks

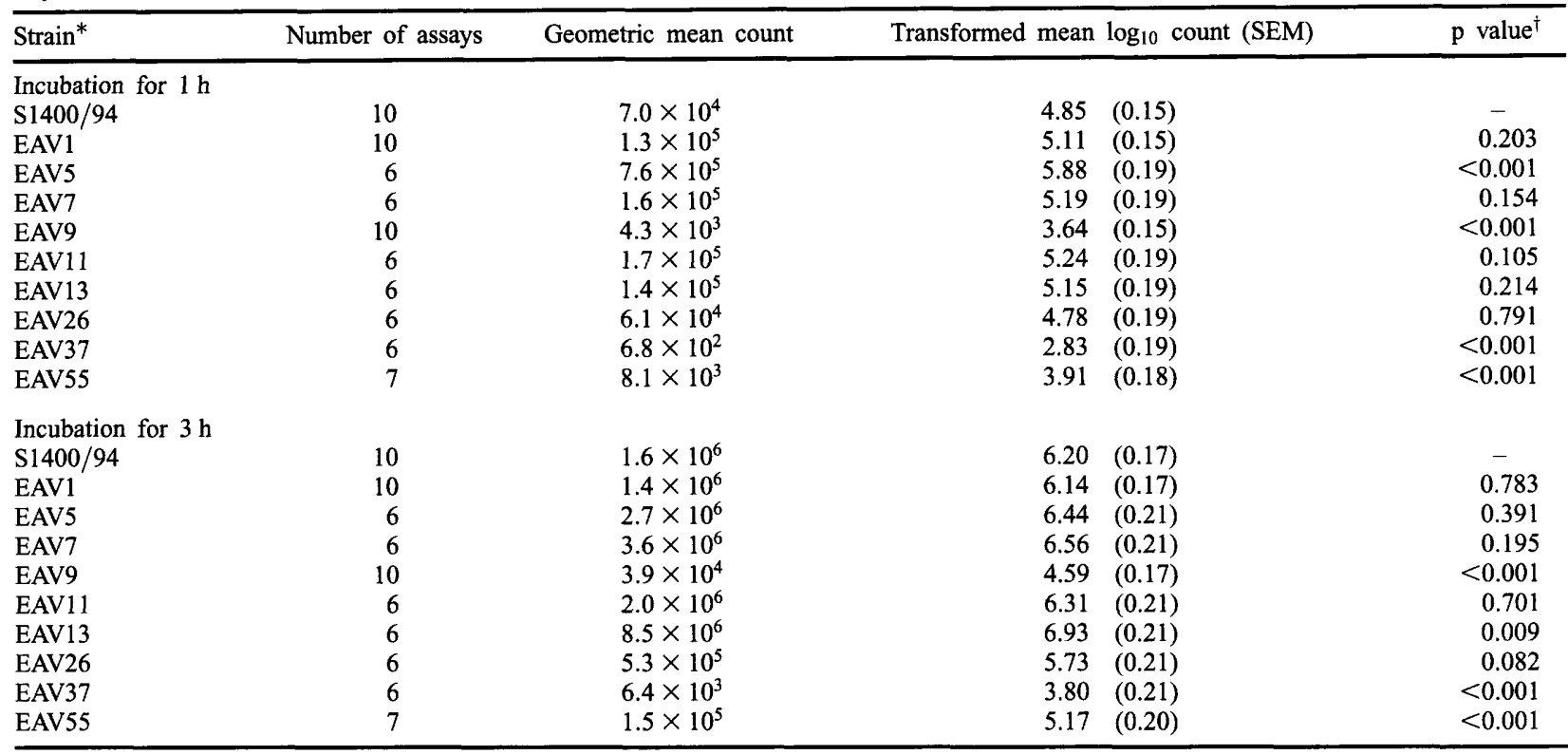

* See Table 4.

${ }^{\dagger} t$ Test versus wild-type. Each strain was compared to the wild-type strain by a $t$ test based on the pooled residual variance from the analyses of variance. A p value $<0.05$ indicates a significant difference from that of the wild-type strain at the $5 \%$ level.

were placed in the bacterial inoculum and (1) shaken, (2) left static and allowed to settle or (3) suspended by sterile cotton thread and left static. Incubation was for $1 \mathrm{~h}$ and each assay was repeated three times. The results are summarised in Table 6. Irrespective of adherence assay, the non-flagellate mutant strain EAV9 was significantly less adherent $(p=0.05)$ than the wild-type strain. The paralysed mutant strain EAV45 was significantly less adherent $(p=0.05)$ in static and suspended assays only, whereas the smooth-swimming chemotaxis-defective mutant strain EAV65 was significantly less adherent $(p=0.05)$ but in the suspended assay only.

\section{Invasion assay}

Attempts were made to assess the extent of bacterial invasion of chick gut epithelial cells in this model. However, it was observed that the integrity of the gut explants failed as incubation was prolonged beyond $c$. $5 \mathrm{~h}$, the minimum time for which initial adherence $(1 \mathrm{~h})$ and gentamicin treatment (a further $3 \mathrm{~h}$ ) was required [22]. This lack of tissue integrity has been reported previously [42] and meaningful data were not obtained.

\section{Discussion}

Allelic exchange is an established technique used to derive defined mutant strains for subsequent phenotypic analysis. Convincing genotypic evidence was gained by Southern hybridisation that the mutant strains were constructed by insertion of antibiotic resistance cassettes within each of the targeted genes. Where testable, as for SEF21, SEF14 and SEF17 fimbriae and non-motile non-flagellate and flagellate derivatives, there was $100 \%$ co-transduction between the relevant phenotype and antibiotic resistance. However, only genotypic evidence was available for insertional inactivation of pef and lpf genes in strain S1400; but this approach has been used successfully to demonstrate the roles of PEF and LPF of Typhimurium $[8,9,11,43]$. It should be borne in mind that other undetected but

Table 6. Comparison of adherence of wild-type and mutant strains in day-old chick gut explants in shaking, static and suspended models

\begin{tabular}{|c|c|c|c|c|c|c|c|c|c|}
\hline \multirow[b]{2}{*}{ Strain no. } & \multicolumn{3}{|c|}{ Geometric mean count } & \multicolumn{6}{|c|}{ Transformed mean $\log _{10}$ count } \\
\hline & Shaken & Static & Suspended & Shaken & $\mathrm{p}$ value* & Static & p value* & Suspended & p value* \\
\hline S1400/94 & $7.0 \times 10^{5}$ & $9.9 \times 10^{4}$ & $1.2 \times 10^{6}$ & 5.84 & - & 5.00 & - & 6.06 & - \\
\hline EAV9 & $4.3 \times 10^{4}$ & $1.8 \times 10^{3}$ & $2.0 \times 10^{3}$ & 4.63 & 0.05 & 3.25 & 0.05 & 3.30 & 0.05 \\
\hline EAV45 & $2.9 \times 10^{5}$ & $1.2 \times 10^{3}$ & $2.0 \times 10^{3}$ & 5.50 & NS & 3.09 & 0.05 & 3.23 & 0.05 \\
\hline EAV65 & $8.5 \times 10^{5}$ & $4.5 \times 10^{4}$ & $3.0 \times 10^{4}$ & 5.93 & NS & 4.65 & NS & 4.48 & 0.05 \\
\hline
\end{tabular}

NS, not significant.

${ }^{*}$ Compared with wild-type and calculated from an analyses of least significant differences (LSD). Any difference between the transformed means which exceeds the LSD is significant at the $5 \%$ level $(\mathrm{p}=0.05)$ by Student's $t$ test. The LSD for a $1-\mathrm{h}$ incubation period is 0.51 and that for $3 \mathrm{~h}$ is 0.43 . 
co-transducible mutational events may have occurred during the construction of the mutant strains, although no evidence for that idea was gained.

The adhesion assay data suggested that flagella were important for adherence and that motility was a significant contributing factor. In the shaken model, bacterial motility was observed to be less important for adherence than the presence of the flagellar structure. A comparison between strains EAV9 (non-flagellate) and EAV45 (paralysed flagella) in both static and hanging models demonstrated that both mutant strains were significantly less able to adhere to gut explants than the wild-type strain. Therefore, it seems unlikely that flagella possess an adhesin, but rather that the adhesive effect is mediated by the morphology of these organelles, a conclusion supported by the findings of Jones et al. [44]. Salmonella flagella are long (5$10 \mu \mathrm{m}$ ), rigid structures, which may promote interaction between bacteria and host by, for example, increasing surface area for initial contact or overcoming repulsive forces. None of the fimbrial kinds appeared to contribute to adherence in any assay. This was a surprising finding considering that type 1 fimbriae are generally known to possess a mannosesensitive adhesin [45] and in this work all assays were performed in the absence of D-mannose. One explanation might be that day-old chick gut lacks relevant fimbrial receptors, possibly due to immaturity [46], or that receptors were masked (e.g., by mucus), although SEM evidence suggested otherwise. Another possible explanation is that strain $\mathrm{S} 1400$ failed to elaborate fimbriae under the growth conditions used for the preparation of inocula. It was known that growth in LB broth was poorly inducing for several of the fimbriae $[38,39,47]$ although induction may have been triggered by the association with explant tissue, a phenomenon reported by others [48]. Recent reports have indicated that LPS $O$ antigen is an important factor for persistence of Typhimurium in the gut of 3week-old chicks, but that fimbriae are not important [49]. It was confirmed that all strains used in the present experiments elaborated the LPS antigens which might have contributed to adherence in this model.

We gratefully acknowledge the assistance of Bill Cooley in electron microscopy and Robin Sayers in statistical analyses. E.A.V. was supported by research grant (DH251.1) from the Department of Health (UK) and M.J.W. was supported by the Ministry for Agriculture Fisheries and Food, GB.

\section{References}

1. Duguid JP, Anderson ES, Campbell I. Fimbriae and adhesive properties in Salmonellae. J Pathol Bacteriol 1996; 92: $107-138$.

2. Lockman HA, Curtiss R. Salmonella typhimurium mutants lacking flagella or motility remain virulent in $\mathrm{BALB} / \mathrm{c}$ mice. Infect Immun 1990; 58: 137-143.

3. Lockman HA, Curtiss R. Isolation and characterization of conditional adherent and non-type 1 fimbriated Salmonella typhimurium mutants. Mol Microbiol 1992; 6: 933-945.
4. Lockman HA, Curtiss R. Virulence of non-type 1-fimbriated and nonfimbriated nonflagellated Salmonella typhimurium mutants in murine typhoid fever. Infect Immun 1992; 60: 491-496.

5. Oyofo BA, Droleskey RE, Norman JO et al. Inhibition by mannose of in vitro colonization of chicken small intestine by Salmonella typhimurium. Poult Sci 1989; 68: 1351-1356.

6. Lee MD, Curtiss R, Peay T. The effect of bacterial surface structures on the pathogenesis of Salmonella typhimurium infection in chickens. Avian Dis 1996; 40: 28-36.

7. Bäumler $\mathrm{AJ}$, Heffron $\mathrm{F}$. Identification and sequence analysis of lpfABCDE, a putative fimbrial operon of Salmonella typhimurium. J Bacteriol 1995; 177: 2087-2097.

8. Bäumler AJ, Tsolis RM, Heffron F. The lpf fimbrial operon mediates adhesion of Salmonella typhimurium to murine Peyer's patches. Proc Natl Acad Sci USA 1996; 93: 279-283.

9. van der Velden AWM, Bäumler AJ, Tsolis RM, Heffron F Multiple fimbrial adhesins are required for full virulence of Salmonella typhimurium in mice. Infect Immun 1998; 66: 2803-2808.

10. Friedrich MJ, Kinsey NE, Vila J, Kadner RJ. Nucleotide sequence of a $13.9 \mathrm{~kb}$ segment of the $90 \mathrm{~kb}$ virulence plasmid of Salmonella typhimurium: the presence of fimbrial synthetic genes. Mol Microbiol 1993; 8: 543-558.

11. Bäumler AJ, Tsolis RM, Bowe FA, Kusters JG, Hoffmann S, Heffron F. The pef fimbrial operon of Salmonella typhimurium mediates adhesion to murine small intestine and is necessary for fluid accumulation in the infant mouse. Infect Immun 1996; 64: $61-68$.

12. Aslanzadeh J, Paulissen LJ. Role of type 1 and type 3 fimbriae on the adherence and pathogenesis of Salmonella enteritidis in mice. Microbiol Immunol 1992; 36: 351-359.

13. Woodward MJ, Allen-Vercoe E, Redstone JS. Distribution, gene sequence and expression in vivo of the plasmid encoded fimbrial antigen of Salmonella serotype Enteritidis. Epidemiol Infect 1996; 117: 17-28.

14. Arnquist A, Olsén A, Pfeifer J, Russell DG, Normark S. The Crl protein activates cryptic genes for curli formation and fibronectin binding in Escherichia coli HB101. Mol Microbiol 1992; 6: 2443-2452.

15. Collinson SK, Emödy L, Müller K-H, Trust TJ, Kay WW. Purification and characterization of thin, aggregative fimbriae from Salmonella enteritidis. J Bacteriol 1991; 173: 47734781 .

16. Collinson SK, Clouthier SC, Doran JL, Banser PA, Kay WW. Salmonella enteritidis agfBAC operon encoding thin, aggregative fimbriae. $J$ Bacteriol 1996; 178: 662-667.

17. Allen-Vercoe E, Dibb-Fuller M, Thorns CJ, Woodward MJ. SEF17 fimbriae are essential for the convoluted colonial morphology of Salmonella enteritidis. FEMS Microbiol Lett 1997; 153: 33-42.

18. Petter JG. Detection of two smooth colony phenotypes in a Salmonella enteritidis isolate which vary in their ability to contaminate eggs. Appl Environ Microbiol 1993; 59: 28842890.

19. Thorns CJ, Sojka MG, Chasey D. Detection of a novel fimbrial structure on the surface of Salmonella enteritidis by using a monoclonal antibody. J Clin Microbiol 1990; 28: 2409-2414.

20. Clouthier SC, Müller K-H, Doran JL, Collinson SK, Kay WW. Characterization of three fimbrial genes, sefABC, of Salmonella enteritidis. J Bacteriol 1993; 175: 2523-2533.

21. Turcotte C, Woodward MJ. Cloning, DNA nucleotide sequence and distribution of the gene encoding the SEF14 fimbrial antigen of Salmonella enteritidis. J Gen Microbiol 1993; 39: 1477-1485.

22. Thorns CJ, Turcotte C, Gemmell CG, Woodward MJ. Studies into the role of the SEF14 fimbrial antigen in the pathogenesis of Salmonella enteritidis. Microb Pathog 1996; 20: 235-246.

23. Thiagarajan $D$, Saeed $M$, Turek J, Asem E. In vitro attachment and invasion of chicken ovarian granulosa cells by Salmonella enteritidis phage type 8. Infect Immun 1996; 64: 5015-5021.

24. Peralta R, Yokoyama H, Ikemori Y, Kuroki M, Kodama Y. Passive immunisation against experimental salmonellosis in mice by orally administered hen egg-yolk antibodies specific for 14-kDa fimbriae of Salmonella enteritidis. $J$ Med Microbiol 1994; 41: 29-35.

25. Penfold RJ, Pemberton JM. An improved suicide vector for construction of chromosomal insertion mutations in bacteria. Gene 1992; 118: $145-146$. 
26. Simon R, Priefer U, Puhler A. A broad host-range mobilisation system for in vivo genetic engineering: transposon mutagenesis in Gram-negative bacteria. Biotech 1983; 1: 784-791.

27. Cooper GL, Venables LM, Woodward MJ, Hormaeche CE. Invasiveness and persistence of Salmonella enteritidis, Salmonella typhimurium, and a genetically defined $S$. enteritidis aro $A$ strain in young chickens. Infect Immun 1994; 62: 4739-4746.

28. Chang ACY, Cohen SN. Construction and characterization of amplifiable multicopy DNA cloning vehicles derived from the P15A cryptic miniplasmid. J Bacteriol 1978; 134: 1141-1156.

29. Flensburg J, Steen R. Nucleotide sequence of the trimethoprim resistant dihydrofolate reductase encoded by $\mathrm{R}$ plasmid $\mathrm{R} 751$. Nucleic Acids Res 1986; 14: 5933.

30. Sambrook J, Fritsch EF, Maniatis T. Molecular cloning - a laboratory manual, 2nd edn. Cold Spring Harbor, NY, Cold Spring Harbor Laboratory Press. 1989.

31. Stock A, Chen T, Welsh D, Stock J. CheA protein, a central regulator of bacterial chemotaxis, belongs to a family of proteins that control gene expression in response to changing environmental conditions. Proc Natl Acad Sci USA 1988; 85: 1403-1407.

32. Purcell BK, Pruckler J, Clegg S. Nucleotide sequences of the genes encoding type 1 fimbrial subunits of Klebsiella pneumoniae and Salmonella typhimurium. J Bacteriol 1987; 169: $5831-5834$.

33. Wei L-N, Joys TM. Covalent structure of three phase-1 flagellar filament proteins of Salmonella. $J \mathrm{Mol}$ Biol 1985; 186: $791-803$.

34. Togashi F, Yamaguchi S, Kihara M, Aizawa S-I, Macnab RM. An extreme clockwise switch bias mutation in fiiG of Salmonella typhimurium and its supression by slow-motile mutations motA and motB. J Bacteriol 1997; 179: 2994-3003.

35. Rose RE. The nucleotide sequence of pACYC184. Nucleic Acids Res 1988; 16: 355.

36. Anderson RJ, Londono LP, Pickard DJ, Dougan G. Development of attenuated Salmonella strains that express heterologous antigens. In: Robinson A, Farrar G, Wiblin C (eds) Methods in molecular medicine: vaccine protocols. Totowa, NJ, Humana Press. 1996: 47-62.

37. Sojka MG, Dibb-Fuller M, Thorns CJ. Characterisation of monoclonal antibodies specific to SEF21 fimbriae of Salmonella enteritidis and their reactivity with other Salmonellae and Enterobacteria. Vet Microbiol 1996; 48: 207-221.

38. Dibb-Fuller M, Allen-Vercoe E, Woodward MJ, Thorns CJ.
Expression of SEF17 fimbriae by Salmonella enteritidis. Lett Appl Microbiol 1997; 25: 447-452.

39. Thorns CJ, Sojka MG, McLaren IM, Dibb-Fuller $M$. Characterisation of monoclonal antibodies against a fimbrial structure of Salmonella enteritidis and certain other serogroup D salmonellae and their application as serotyping reagents. Res Vet Sci 1992; 53: 300-308.

40. Gyimah JE, Panigrahy B. Adhesin-receptor interactions mediating the attachment of pathogenic Escherichia coli to chicken tracheal epithelium. Avian Dis 1988; 32: 74-78.

41. Gutterson NI, Koshland DE. Replacement and amplification of bacterial genes with sequences altered in vitro. Proc Natl Acad Sci USA 1983; 80: 4894-4898.

42. Droleskey RE, Oyofo BA, Hargis BM, Corrier DE, DeLoach JR. Effect of mannose on Salmonella typhimurium-mediated loss of mucosal epithelial integrity in cultured chick intestinal segments. Avian Dis 1994; 38: 275-281.

43. Bäumler AJ, Tsolis RM, Heffron F. Contribution of fimbrial operons to attachment to and invasion of epithelial cell lines by Salmonella typhimurium. Infect Immun 1996; 64: 18621865.

44. Jones GW, Richardson LA, Uhlman D. The invasion of HeLa cells by Salmonella typhimurium: reversible and irreversible bacterial attachment and the role of bacterial motility. $J$ Gen Microbiol 1981; 127: 351-360.

45. Kukkonen M, Raunio T, Virkola $\mathrm{R}$ et al. Basement membrane carbohydrate as a target for bacterial adhesion: binding of type 1 fimbriae of Salmonella enterica and Escherichia coli to laminin. Mol Microbiol 1993; 7: 229-237.

46. Jeurissen SHM, Janse EM, Koch G, De Boer GF. Postnatal development of mucosa-associated lymphoid tissues in chickens. Cell Tissue Res 1989; 258: 119-124.

47. Walker SL, Sojka M, Dibb-Fuller M, Woodward MJ. The effect of $\mathrm{pH}$, temperature and surface contact on the elaboration of fimbriae and flagella by Salmonella enteritidis. $J$ Med Microbiol 1999; 48: 253-261.

48. Finlay BB, Heffron F, Falkow S. Epithelial cell surfaces induce Salmonella proteins required for bacterial adherence and invasion. Science 1989; 243: 940-943.

49. Turner AK, Lovell MA, Hulme SD, Zhang-Barber L, Barrow PA. Identification of Salmonella typhimurium genes required for colonization of the chicken alimentary tract and for virulence in newly hatched chicks. Infect Immun 1998; 66: 2099-2106. 